\title{
Oropharyngeal lipoma; a rare and dangerous cause of voice change
}

\author{
Jessica Lunn, Rajeev Mathew, Prince Modayil
}

St George's Hospital, London, UK

\section{Correspondence to Jessica Lunn, jessicalunn@nhs.net}

Accepted 26 June 2019

\section{DESCRIPTION}

A 28-year-old man presented to the ear, nose and throat outpatients clinic with a 5 year history of voice change and a 1 year history of dysphagia and worsening shortness of breath on lying prone. His partner had noted recent noisy breathing at night. He was systemically well with no past medical history of note and smoked 5 cigarettes/week. On examination he had a 'hot potato' voice. Flexible nasendoscopy revealed a large right-sided mass that appeared to arise from the vallecula and occupied most of the oropharynx, with only the posterior glottis visible. CT imaging revealed a $56 \times 38 \times 26 \mathrm{~mm}$ lesion occupying the right vallecula causing significant airway obstruction (figure 1). Its contents were consistent with a fatty lesion. The following day he underwent awake fibreoptic intubation, debulking of the lesion orally followed by laryngoscopy and endoscopic excision. Histology confirmed a submucosal benign lipoma.

Lipomas are rarely found in the upper aerodigestive tract, making up only $1-4 \%$ of all benign tumours of the oropharynx and oral cavity. ${ }^{1}$ These tumours are typically slow growing. However, they have the potential to cause airway obstruction depending on size and location and have been reported to cause stridor and death. ${ }^{23}$

Oropharyngeal lipomas have typical characteristics on CT and MRI and therefore imaging of these lesions is important for diagnosis but also for anaesthetic

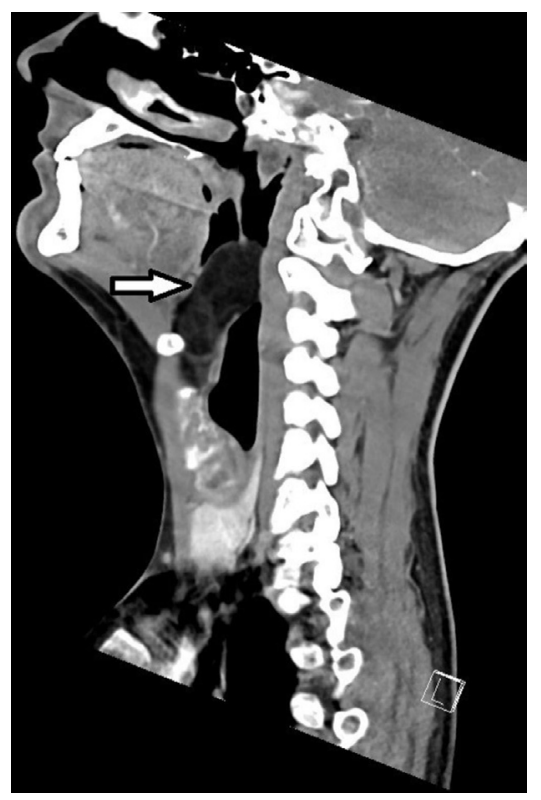

Figure 1 Sagittal CT of the neck shows lipoma in the vallecula (arrow).

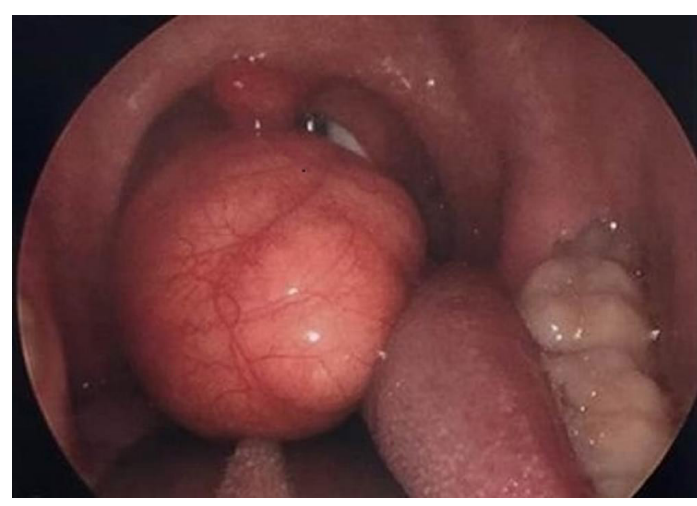

Figure 2 Prolapse of the lipoma into the oral cavity intraoperatively.

and surgical planning. On CT, they appear as well defined, non-enhancing, low attenuation (65-125 Hounsfield Units) homogenous lesions, as demonstrated in this case. ${ }^{45}$ The differential diagnoses of vallecular lesions include malignant tumours, benign vallecular cysts such as mucous retention cysts and dermoid or epidermoid cysts. ${ }^{5}$ A lipoma located in a different area of the upper aerodigestive tract, such as the larynx, should also be considered as a differential diagnosis for clinical presentations such as that described in this case. ${ }^{6}$

Due to the soft and mobile nature of these lipomatous lesions, there is a risk of prolapse into the oral cavity (figure 2) leading to total obstruction of the airway during induction of anaesthesia. ${ }^{7}$ Therefore, careful anaesthetic assessment is required for all suspected oropharyngeal lipomas with consideration of positioning and awake fibreoptic intubation techniques.

\section{Patient's perspective}

I had had the symptoms for around 4 or 5 years by the time I finally got diagnosed.

Until then I had found myself going to a GP either annually or biannually with the same throat issues. It was a frustrating time because close friends and relatives (some of whom work within the NHS) continued to show concern about my voice changes but GPs up to that point were quite dismissive and twice gave me a nasal spray which was completely ineffective.

When I could feel a lump within my throat that was gradually increasing in size, it made me think that I had cancer or a tumour of some sort. This was obviously a very scary prospect. 


\section{Learning points}

Patients with insidious onset of voice change should have flexible nasendoscopic assessment of their larynx.

- Consider lipoma in the differential diagnosis of lesions of the vallecula.

- Careful assessment and consideration of awake fibreoptic intubation is essential for large oropharyngeal lesions in order to prevent total airway obstruction during anaesthesia.

Contributors JL: patient care, and planning, design and writing of the case report. RM: patient care, and planning and revising of the case report. PM: patient care, and review and editing of the drafts. All authors were involved in the final approval for submission, including agreement to accountability for the work.

Funding The authors have not declared a specific grant for this research from any funding agency in the public, commercial or not-for-profit sectors.
Competing interests None declared.

Patient consent for publication Obtained.

Provenance and peer review Not commissioned; externally peer reviewed.

\section{REFERENCES}

1 Tan KS, Jalaluddin WMS. Lipoma of vallecula-a case report. BJR Case Rep 2016;2:20150460

2 Persaud RA, Kotnis R, Ong CC, et al. A rare case of a pedunculated lipoma in the pharynx. Emerg Med I 2002;19:275.

3 Mitchell JE, Thorne SJ, Hern JD. Acute stridor caused by a previously asymptomatic large oropharyngeal spindle cell lipoma. Auris Nasus Larynx 2007;34:549-52.

4 Som PM, Scherl MP, Rao VM, et al. Rare presentations of ordinary lipomas of the head and neck: a review. AJNR Am J Neuroradiol 1986;7:657-64.

5 Lahiri AK, Somashekar KK, Wittkop B, et al. Large vallecular masses; differential diagnosis and imaging features. J Clin Imaging Sci 2018;8:26.

6 Wolf-Magele A, Schnabl J, Url C, et al. Acute dyspnea caused by a giant spindle cell lipoma of the larynx. Wien Klin Wochenschr 2016;128(3-4):146-9.

7 Rimmer J, Singh A, Irving C, et al. Asymptomatic oropharyngeal lipoma complicating intubation. J Laryngol Otol 2005;119:483-5.

Copyright 2019 BMJ Publishing Group. All rights reserved. For permission to reuse any of this content visit

https://www.bmj.com/company/products-services/rights-and-licensing/permissions/

BMJ Case Report Fellows may re-use this article for personal use and teaching without any further permission.

Become a Fellow of BMJ Case Reports today and you can:

- Submit as many cases as you like

- Enjoy fast sympathetic peer review and rapid publication of accepted articles

- Access all the published articles

Re-use any of the published material for personal use and teaching without further permission

\section{Customer Service}

If you have any further queries about your subscription, please contact our customer services team on +44 (0) 2071111105 or via email at support@bmj.com.

Visit casereports.bmj.com for more articles like this and to become a Fellow 